\title{
MOSES MAIMONIDES ON JOB'S HAPPINESS AND THE RIDDLE OF DIVINE TRANSCENDENCE
}

\author{
N. VERBIN \\ Tel-Aviv University
}

\begin{abstract}
The paper explores the nature and role of divine transcendence in Maimonides by focusing on the figure of Job as he is understood by him. In the first part, I discuss Maimonides' diagnosis of Job's suffering. In the second, I focus on Maimonides' analysis of the nature of its defeat, and the manners in which that defeat involves the mediation of divine transcendence and hiddenness. In the third, I discuss some of the difficulties involved within the picture presented in the second part, namely, Maimonides' seeming commitment to two incompatible conceptions of divine transcendence. I argue that the incompatible accounts need not be harmonized since the Guide of the Perplexed is not a textbook that attempts to provide a doctrine concerning the nature of divine transcendence and its relation to the world. Rather, its purpose is to present a riddle, the great riddle of divine transcendence, around which Jewish life, as he understands it, is built. This riddle, for Maimonides, cannot be solved or dissolved; rather, it has to be recognized and embraced.
\end{abstract}

The purpose of the paper is to explore the nature and role of divine transcendence in Maimonides by focusing on the figure of Job as he is understood by him. I will explore the ways in which Maimonides attempts to undermine the religious protest that is voiced by Job, the ways in which he construes Job's defeat of suffering, and how these are related to his conception of the intellect as the locus in which God's transcendence is mediated.

The paper contains three parts. In the first, I discuss Maimonides' diagnosis of Job's suffering. In the second, I focus on Maimonides' analysis of the nature of its defeat, and the manners in which that defeat 
involves the mediation of divine transcendence and hiddenness. In the third part, I discuss some of the difficulties involved within the picture presented in the second part, namely, Maimonides' seeming commitment to two incompatible conceptions of divine transcendence. I argue that the incompatible accounts need not be harmonized since the Guide of the Perplexed is not a textbook that attempts to provide a doctrine concerning the nature of divine transcendence and its relation to the world. Rather, its purpose is to present a riddle, the great riddle of divine transcendence, around which Jewish life, as he understands it, is built. This riddle, for Maimonides cannot be solved or dissolved; rather, it has to be recognized and embraced.

\section{JOB'S SUFFERING}

An encounter with the book of Job faces us with a knight of protest. Job does not experience God's hiddenness. He experiences God as present in every single moment, taking every effort to torment him in every possible way:

Let me be for my days are a breath. What is man that you make much of him that you fix your attention upon him? You inspect him every morning, examine him every minute. Will you not look away from me for a while, let me be till I swallow my spittle? (7: 16-19)

Job does not lovingly submit to the divine afflictions. He feels humiliated by the divine attack, perceiving it as a divine assault against him, as a divine abuse. He protests. He complains to God: 'Does it benefit You to defraud, to despise the toil of Your hands, while smiling on the counsel of the wicked?' (10:3). He states: 'God has wronged me; He has thrown up siege works around me. I cry, "Violence!" but am not answered; I shout, but can get no justice.' (19:6-7). I have argued elsewhere that Job does not retract the content of his accusations after the divine revelations. His protest comes to a halt as a result of his realization that there is no point in addressing God any longer; I have argued that the book of Job ends with Job's forgiving God, while refusing to be reconciled with Him (Verbin 2010).

Various readers of the book of Job, however, interpret the scope of Job's protest and its significance differently. Indeed Maimonides downplays the meaning and role of Job's protest, judging it insignificant, perceiving 
it as resulting from Job's ignorance of God. In his Guide of the Perplexed, he makes the following comments concerning Job and his protest:

The latter [Job] said all that he did say as long as he had no true knowledge and knew the deity only because of his acceptance of authority, just as the multitude adhering to the Law know it. (III/23, p. 492) ${ }^{1}$

And:

The most marvellous and extraordinary thing about this story is the fact that knowledge is not attributed in it to Job. He is not said to be a wise or a comprehending or an intelligent man. Only moral virtue and righteousness in action are ascribed to him. For if he had been wise, his situation would not have been obscure for him ... (III/22, p. 487)

Maimonides, here, clearly maintains that Job's protest results from his ignorance; it is due to his ignorance that his situation had seemed obscure to him.

Maimonides seems to presuppose, in these passages, a distinction between pain, disease and loss, on the one hand, and the suffering that they characteristically produce, on the other. The distinction is, I believe, a helpful one and the two are to be conceptually distinguished. Pain is a sensation, which is located in a specific bodily organ. It is not intentional; it does not involve concepts, judgments or beliefs. Suffering, unlike pain, is not located in a specific bodily organ. It defines the person as a whole. When one suffers, suffering overtakes one's whole being; it defines the suffering person as a sufferer. Moreover, suffering, unlike pain, is intentional. We suffer from something, just as we are afraid of something or angry at someone. Suffering is not a mere physical mechanistic response to stimulation of a certain type; it involves concepts, judgments or beliefs. It involves, e.g., the sufferer's belief that what he or she is enduring, the pain or the loss, is bad, undesirable, of negative significance. Had it not been for these beliefs or judgments, the sufferer would not have been a sufferer. He or she may have been in great pain; he or she may have lost property, social status etc. Without considering the loss as a significant one, s/he would not have suffered on its account. ${ }^{2}$ Suffering, therefore, involves a way of looking at something or evaluating

\footnotetext{
${ }^{1}$ All reference to Maimonides within the text are to Moses Maimonides, The Guide of the Perplexed, trans. by Shlomo Pines (Chicago: University of Chicago Press, 1963).

${ }^{2}$ Childbirth, which involves a great deal of pain and, often, joy and happiness at the same time, is a useful example of the conceptual distinction between pain and suffering.
} 
something, which is often accompanied by various sensations that show themselves in characteristic ways of acting, and which are related to various psycho-physiological processes. ${ }^{3}$

Job, according to Maimonides, did not suffer due to his loss of property and children nor did he suffer due to his disease and pain. Job suffered due to his faulty way of understanding his pain and loss, due to his faulty way of relating to the facts:

The latter [Job] said all that he did say as long as he had no true knowledge and knew the deity only because of his acceptance of authority, just as the multitude adhering to the Law know it. But when he knew God with a certain knowledge, he admitted that true happiness, which is the knowledge of the deity, is guaranteed to all who know Him and that a human being cannot be troubled in it by any of all the misfortunes in question. While he had known God only through the traditional stories and not by the way of speculation, Job had imagined that the things thought to be happiness, such as health, wealth, and children, are the ultimate goal. For this reason he fell into such perplexity and said such things as he did. (III/23, pp. 492-493)

Pain, for Maimonides, has to do with matter, with the frailty of our body, which is subject to time, to change, to disease and to death. Both the wise and the unwise are susceptible to the contingency of matter, to aging, injury and death; the lives of both involve pain due to the matter from which they are created:

All passing away and corruption or deficiency are due solely to matter ... Similarly every living being dies and becomes ill solely because of its matter and not because of its form. (III/8, p. 431)

Although both the wise and the unwise are vulnerable due to their bodily existence, the unwise are more so. The unwise are immersed in matter; being immersed in matter, they indulge in practices that are harmful to the body, that bring about and enhance disease, pain and sorrow. Maimonides believes that self-produced evils are the most prevalent ones:

The evils of the third kind [i.e., self-produced evils] are those that are inflicted upon any individual among us by his own action; this is what happens in the majority of cases ... This kind is consequent upon all vices,

\footnotetext{
${ }^{3}$ For more on the distinction between pain and suffering, see, e.g., Edwards 2003 and Cornevale 2009.
} 
I mean concupiscence for eating, drinking, and copulation, and doing these things with excess in regard to quantity or irregularly or when the quality of the foodstuffs is bad. For this is the cause of all corporeal and psychical diseases and ailments. (III/12, pp. 445-446)

Physical indulgence, for example, results in physical illness as well as in various vices that lead the unwise to pursue unnecessary aims the attainment of which involves a greater dependency on chance, greater risks, and, therefore, a greater deal of pain and sorrow:

With regard to the diseases of the soul due to this evil regimen, they arise in two ways: In the first place, through the alteration necessarily affecting the soul in consequence of the alteration of the body, the soul being a corporeal faculty ... and in the second place, because of the fact that the soul becomes familiarized with, and accustomed to, unnecessary things and consequently acquires the habit of desiring things that are unnecessary either for the preservation of the individual or for the preservation of the species; and this desire is something infinite... Thus every ignoramus who thinks worthless thoughts is always sad and despondent because he is not able to achieve the luxury attained by someone else. In most cases, such a man exposes himself to great dangers, such as arise in sea voyages and the service of kings; his aim therein to obtain these unnecessary luxuries ... (III/12, pp. 445-446)

If we wish to avoid unnecessary pain, disease and loss, our form, our reason is to rule our physical impulses:

He [God] granted it - I mean the human form - power, dominion, rule and control over matter, in order that it subjugate it, quell its impulses, and bring it back to the best and most harmonious state that is possible. (III/ 8, p. 432)

Some are successful in doing so:

There are among men individuals to whose mind all the impulses of matter are shameful and ugly things, deficiencies imposed by necessity ... A man should be in control of all these impulses, restrict his efforts in relation to them, and admit only that which is indispensable. He should take as his end that which is the end of man qua man: namely, solely the mental representation of the intelligibles, the most certain and the noblest of which being the apprehension, in as far as this is possible, of the deity, of the angels, and of His other works. These individuals are those who are permanently with God ... (III/8, pp. 432-433) 
The life of such a person who is 'permanently with God' is a happy one. Such a person is characteristically free from ailments, both physical and psychic; he is characteristically free from both sickness and sorrow. Moreover, his form no longer struggles to quench matter; it no longer needs to control it. It reaches a state in which it transcends matter. The individual of perfect apprehension then comes to live a somewhat divided life, living in two parallel plains: one that has to do with his ordinary actions and interactions: eating, drinking, caring for his livelihood etc.; the other, which remains uninterrupted by the former, has to do with his contemplation of the divine name:

And there may be a human individual who, through his apprehension of the true realities and his joy in what he has apprehended, achieves a state in which he talks with people and is occupied with his bodily necessities while his intellect is wholly turned toward Him, may He be exalted, so that in his heart he is always in His presence, may he be exalted, while outwardly he is with people, in the sort of way described by the poetical parables that have been invented for these notions: I sleep but my heart waketh ... (III/51, p. 623)

The defeat of suffering is intrinsically related to reason's capacity to transcend matter, in this way, and turn to God. When matter is transcended, the pain and loss that are related to matter are transcended along with it while the intellect is filled with the joy of apprehending God.

Although our reason can transcend matter and the pain to which it is susceptible, it cannot eliminate the pain. Although all illnesses, physical and psychical are self-produced, although 'the cause of all corporeal and psychical diseases and ailments' is our own actions, it does not follow that pain can be eliminated by wisdom. Natural disasters may injure us; we may fall prey to others' wrongful actions. Even the wise prophet may have to endure the pain of execution that directly results from his flawless actions qua prophet:

But the nature of that intellect is such that it always overflows and is transmitted from one who receives that overflow to another one who receives it after him until it reaches an individual beyond whom this overflow cannot go and whom it merely renders perfect, as we have set out in a parable in one of the chapters of this Treatise. The nature of this matter makes it necessary for someone to whom this additional measure of overflow has come, to address a call to people, regardless of whether 
that call is listened to or not, and even if he as a result thereof is harmed in his body. We even find that prophets addressed a call to people until they were killed - this divine overflow moving them and by no means letting them rest and be quiet, even if they met with great misfortunes. $(\mathrm{II} / 57, \text { p. } 375)^{4}$

The pain that such a prophet experiences, however, produces no suffering. The prophet's bodily existence subsists on a different plain.

Thus, while pain and loss cannot be completely abolished, the suffering and sorrow that they characteristically produce can be done away with. Ascribing no particular significance to the well-being of his body or to its subsistence, the wise person does not suffer by the injuries that afflict it or by its loss. His intellect transcends his body while contemplating the divine name, disregarding the pain and the loss, considering it insignificant and external to its very being. The contemplative life is, therefore, the happy life, and the happy life is the contemplative life. Suffering, for Maimonides, is, thus, a symptom of a bad life. It is defeated - it is abolished - by wisdom, by knowledge.

\section{JOB'S HAPPINESS}

Maimonides, however, has famously emphasized God's transcendence, His hiddenness, both to our reason and to our senses. He has famously insisted that God's nature cannot be known:

all men, those of the past and those of the future, affirm clearly that God, may He be exalted, cannot be apprehended by the intellects, and that none but He Himself can apprehend what He is ... (I/59, p. 139)

Given God's hiddenness, what can the Maimonidean sage know? What kind of knowledge constitutes the Maimonidean sage as a sage? What kind of knowledge did Job acquire, which had liberated him from suffering?

It may appear as if the Maimonidean sage possesses two types of knowledge: propositional knowledge and non-propositional knowledge.

${ }^{4}$ I judge this paragraph, along with Part III/22, 23 and the description of the climactic deaths of Moses Aaron and Miriam in III/51 as conclusive evidence for the thesis that Maimonides was committed to the 'contemplative' conception of divine providence. According to this conception, the individual of perfect apprehension who enjoys God's providence to its fullest is not protected from physical harm but from the suffering that it may bring forth. 
It may appear as if the propositional component can be expressed by means of Maimonides' negative theology. The Maimonidean sage, presumably, knows that he cannot apply any positive attribute to describe God. He cannot describe God as eternal, omnipotent, omniscient or perfectly benevolent.

The Guide seems to contain arguments that purport to justify that inability. These arguments, however, rely on sub-arguments that function as presuppositions concerning God's nature, e.g., that God is one, perfect and eternal. In other words, Maimonides implicitly assumes various truths about God's nature. He states, for example:

With regard to those three groups of attributes - which are the attributes indicative of the essence or of a part of the essence or of a certain quality subsisting in the essence - it has already been made clear that they are impossible with reference to Him, may He be exalted, for all of them are indicative of composition, and the impossibility of composition in respect to the deity we shall make clear by demonstration. (I/52, p. 116)

If these presuppositions are true then the conclusions that follow from them, namely, that we cannot ascribe any perfections to God, that we cannot state that God is in-composite, immutable, eternal etc., are false. If the presuppositions concerning God's nature are false, then they cannot justify Maimonides' conclusions. Thus, the Maimonidean sage cannot be defined as a sage by possessing propositional knowledge of what God is or is not.

Realizing that, Lorberbaum argues that the utterances of the Guide are poetic. They do not make statements that can be true or false but they attempt to bring about a change in the ways in which we speak about God and worship Him by the use of poetic means (Lorberbaum 2011).

Seeskin argues that the Guide has propositional content, albeit a flawed one. Its propositions miss the mark:

Obviously Maimonides would not say that every claim we make about God is nonsensical. But he would say that the claims we make about God are best understood as steps on the way to something higher: a perspective from which we see that strictly speaking nothing we say about God can be true. (Seeskin 2000: 35)

I have elsewhere argued that the propositions of the Guide cannot be merely false; their failure, and the failure of each and every utterance about God (if it is to be understood as truly about God) is categorical, 
for Maimonides, and, as such, deeper than the failure of falsity; it is incoherent nonsense (Verbin 2011).

Whether the utterances of the Guide are poetic, meaningless or simply deficient, it appears that the knowledge that the Maimonidean sage possesses cannot be understood as propositional knowledge of what God is or is not.

Although the Maimonidean sage is not in possession of propositional knowledge about God, although he cannot speak about God, he can refer to God. ${ }^{5} \mathrm{He}$ can do so by means of God's proper name, YHWH:

All the names of God, may He be exalted, that are to be found in any of the books derive from actions. There is nothing secret in this matter. The only exception is one name: namely Yod, $\mathrm{He} \mathrm{Vav}, \mathrm{He}$. This is the name of God, may He be exalted, that has been originated without any derivation, and for this reason it is called the articulated name. This means that this name gives a clear unequivocal indication of His essence, may He be exalted. On the other hand, all the other great names give their indication in an equivocal way, being derived from terms signifying actions the like of which ... exist as our own actions ... Generally speaking, the greatness of this name and the prohibition against pronouncing it are due to its being indicative of the essence of Him, may He be exalted, in such a way that none of the created things is associated with Him in this indication.

(I/ 61, pp. 147-148)

The Maimonidean sage who has cleansed his mind of the false images of God that it tends to produce can contemplate the divine name. It is this content-less mystical contemplation of what cannot be said in meaningful propositions but can only be shown that constitutes the Maimonidean sage as a sage. ${ }^{6,7}$ It is in that contemplation that divine transcendence is mediated and suffering is defeated.

Maimonides uses different metaphors for the non-propositional, mystical contemplation of God, among which are the metaphors of 'beauty' and of a 'bright light':

\footnotetext{
${ }^{5}$ On meaning and reference in Maimonides, see Benor (1995: 347).

6 This is, of course, a reference to the early Wittgenstein's distinction in the Tractatus, between what can be said and what can only be shown. See Wittgenstein 1988.

${ }^{7}$ I am here joining the minority of interpreters who read the Guide as philosophical mysticism. A prominent proponent of this interpretation of the Guide is David Blumenthal (Blumenthal 2006).
} 
all the philosophers say: We are dazzled by His beauty, and He is hidden from us because of the intensity with which He becomes manifest, just as the sun is hidden to eyes that are too weak to apprehend it. (I/59, p. 139)

And elsewhere:

Sometimes truth flashes out to us so that we think it is day, and then matter and habit in their various forms conceal it so that we find ourselves again in an obscure night, almost as were at first. (I/Introduction, p. 7)

In his discussion of divine providence (whose nature too, Maimonides construes in terms of the human capacity for apprehending God) Maimonides characterizes the climactic moment of apprehension to which Moses, Aaron and Miriam have ascended, a moment during which they transcended language and the world, transcended their body and its contingency, transcended suffering and sorrow, in terms of 'intense passionate love', in terms of a 'divine kiss':

[W] hen a perfect man is stricken with years and approaches death, this apprehension increases very powerfully, joy over this apprehension and a great love for the object of apprehension become stronger, until the soul is separated from the body at that moment in this state of pleasure. Because of this the Sages have indicated with reference to the deaths of Moses Aaron, and Miriam that the three of them died by a kiss ... Their purpose was to indicate that the three of them died in the pleasure of this apprehension due to the intensity of passionate love. (III/51, pp. 627-628)

The Maimonidean sage is wholly protected from the sea of chance, from every type of harm. Nothing and no one can undo him. Nothing and no one can cause him terror and distress and separate him from God. He is happy in the pleasure of his passionate loving intellectual mystical apprehension of God. Death and dying too, whether they are caused by the arrows of the battlefield, the snare of the fowler or by natural causes, are not agonizing experiences for the individual of perfect apprehension. For him, the moment of death is a moment of intense pleasure and love, during which his intellect is freed from its attachment to the body, freed to contemplate the divine name more fully than it could ever have contemplated it when it was attached to a body. ${ }^{8}$

\footnotetext{
${ }^{8}$ It is, thus, clear that for Maimonides, there is no tie between faith and suffering. Loving God rightly, too, does not produce sorrow. On the contrary, it produces a great deal of joy. It liberates the individual of perfect apprehension from the world while his body remains susceptible to the laws that govern it. It does not involve any sacrifices.
} 
Maimonides's Job too, after the divine revelations, had acquired such liberating mystical knowledge, and transcended the pain and the loss that he had endured by means of that knowledge. Transcending his previous misconceptions about God and about the genuine causes of his suffering, he had acquired true happiness and ceased to protest. Maimonides believes that from within that elevated state Job retracted his complaints and accusations, stating 'I recant and relent being but dust and ashes' (Job 42:6); he believes that it is in reference to that elevated state that the book of Job has God say to Job's friends, 'You did not speak correctly as did My servant Job’ (Job 42:7).

\section{THE RIDDLE OF TRANSCENDENCE}

Maimonides' discussion of the divine attributes involves three dimensions of transcendence: linguistic, epistemic and metaphysical: Maimonides seems to deny the possibility of speaking about God, knowing anything about Him, as well as of being in any relation whatsoever to Him. The metaphysical dimension shows itself particularly in the Guide I/52, where Maimonides explicates God's metaphysical transcendence in relation to His incorporeality:

There is no relation between God, may He be exalted, and time and place; and this is quite clear. For time is an accident attached to motion, when the notion of priority and posteriority is considered in the latter and when motion becomes numbered, as is made clear in the passages especially dealing with this subject. Motion, on the other hand, is one of the things attached to bodies, whereas God, may He be exalted, is not a body. Accordingly there is no relation between Him and time, and in the same way there is no relation between Him and place. (I/52, p. 117) Thus:

There is, in truth, no relation in any respect between Him and any of His creatures ... How then could there subsist a relation between Him, may He be exalted, and any of the things created by Him, given the immense difference between them with regard to the true reality of their existence, than which there is no greater difference? (I/52, p. 118)

Nothing that truly matters is given up. It involves our coming to see rightly. It involves our shedding our ignorance, our misperceived views about what does and does not matter; it involves a happy mystical contemplation of the divine name during which God's transcendence is mediated and the sage is released from his/her body while everything stays in place. 
While the non-propositional mystical content of the apprehension that eliminates suffering seems compatible with the linguistic and epistemic limitations that Maimonides discusses, it fails to cohere with the metaphysical limitations. While the mystical apprehension does not provide the sage with anything that he could say or know about God, it places him in relation with God, thereby compromising God's metaphysical transcendence. In other words, if there is a mystical, non-propositional contemplation of the divine name, which 'gives a clear unequivocal indication of His essence' (I/61, p. 148) then there is a relation between God and human beings.

The mystical moment of contemplation of the divine name that defeats suffering and modifies divine transcendence, is related to a variety of issues in the Guide, among which are prophecy, providence, cosmology and creation. Maimonides' account of these themes is derived from his metaphor of the divine intellectual overflow, in terms of which these concepts are developed. It is clear that if there is an overflow of divine intellect into creation in general, and into the happy philosopher/ prophet who is capable of absorbing it in his mystical contemplation in particular, then absolute transcendence is modified in the operation of a variety of mechanisms. Maimonides seems to be committed to the metaphor of the overflow of divine intellect:

This term, I mean 'overflow' is something also applied in Hebrew to God, may He be exalted, with a view to likening Him to an overflowing spring of water ... For nothing is more fitting as a simile to the action of one that is separate from matter than this expression, I mean 'overflow'. (II/12, p. 279)

Thus, two incompatible positions regarding divine transcendence clearly appear in the Guide. Is Maimonides committed to God's absolute transcendence, to His having no relation to the world, or is he committed to the existence of a divine intellectual overflow that flows into creation?

Blurring the distinction between the epistemological and the metaphysical dimensions of transcendence, Gruenwald characterizes the dilemma of divine transcendence with the following words:

On the one hand, there is the idea of God's absolute and incomprehensible transcendence, according to which he is beyond the direct and positive cognition of man. On the other hand, we have the idea of the divine overflow which emanates from God through the Active Intellect and which under certain, though rare, conditions reaches out to man, who in 
turn finds in it a stimulant and means of being elevated to that self-same Active Intellect. We may see the Active Intellect as the meeting place of the emanating divine overflow with the human intellect ... (Gruenwald 1991: 145)

The tension between the 'absolute transcendence concept' of the deity and the 'qualified transcendence concept' was treated in a variety of ways by Maimonides' scholars. ${ }^{9}$ Recognizing the tension, Davies attempts to provide an interpretation that harmonizes the two conceptions, embracing a careful version of the 'qualified transcendence concept'. Addressing the linguistic and epistemological dimensions of divine transcendence, he argues that

Maimonides's account of God's knowledge should be seen as an account of the unlimited perfection of knowledge ... Maimonides is able to consider God to be an intellect without compromising his explanations of religious language; both can be held in tandem and in harmony. (Davies 2011:103)

Even-Chen views the tension as 'essential and indubitable' and argues for the qualified transcendence concept, maintaining that Maimonides' true position is that God is an intellect (Even-Chen 2008: 19-45). Pines argues for an esoteric sceptical reading which rejects the qualified transcendence concept and opts for absolute transcendence. He denies that metaphysical knowledge is possible, insisting that the purpose of the Guide is ethical and political (Pines 1979); Reines too, argues for the absolute transcendence concept, which renders the traditional notions of providence and prophecy 'imaginary fantasies' (Reines 1986).

Over and against these interpretative strategies, some wish to preserve the dialectic nature of the Guide, insisting that Maimonides is committed to both positions. Viewing the tensions within the Guide as resulting from Maimonides' commitment to both philosophy and the Law, Gruenwald states:

In trying to account for Maimonides' differing positions we should not resort to apologetic harmonization, nor should we press too hard to unearth 'either-or' solutions which restrict the area of dialectical implications ... The ultimate question regarding Maimonides'

${ }^{9} \mathrm{I}$ am here following Reines in characterizing the tension between the different conceptions of transcendence as between an 'absolute' and a 'qualified' concept of transcendence. See Reines 1986. 
philosophical thought is whether there is more than one set of tracks that lead to the top of the mountain ... Since in several cases ... Maimonides' deliberations move in circular form, we do more justice to the master's thought if we adopt such an attitude rather than an esoteric mode of reading Maimonides, or artificial harmonization. (Gruenwald 1991: 154-155) $)^{10}$

While I find Gruenwald's position helpful in taking seriously both horns of the dilemma of divine transcendence, I believe that it fails to provide us with a strategy for understanding and interpreting the Guide. How are we to understand the purpose of the Guide, if Maimonides presents, argues for, and endorses two incompatible positions regarding divine transcendence in it? A biographical explanation that appeals to Maimonides' commitment to both philosophy and the Law is of no use in this context.

I would like to propose a different interpretative strategy for understanding the Guide. I propose that we approach the Guide as a great riddle. ${ }^{11}$ Approaching it as a riddle entails that we are not to attempt to harmonize its contradictory accounts of transcendence nor are we to dispense with any horn of the dilemma of divine transcendence. It entails that the Guide is not to be read as a textbook that provides us with a doctrine (or two doctrines) concerning divine transcendence, with propositions that are to be evaluated as true or false, justified or unjustified. Rather, as a riddle, its purpose is to present the fundamental dilemma of divine transcendence in its most poignant form, insisting that the great riddle of divine transcendence admits of neither a solution nor a dissolution. The Guide's complicated and incompatible threads regarding divine transcendence call its ideal reader to embrace the riddle, to leap into it, pointing out that the riddle is embodied in Jewish life. ${ }^{12}$

\footnotetext{
${ }^{10}$ Gruenwald's metaphor of the different tracks that lead to the top of the mountain is problematic too, since different conceptions of the nature of the 'top of the mountain' appear in the Guide, as he himself notes, in relation to philosophy and prophecy.

${ }^{11}$ Approaching the issue of transcendence in the Guide as a great riddle is inspired by Cora Diamond's treatment of Anselm's proof in her 'Riddles and Anselm's Riddle' (Diamond 1995) and particularly by Patt-Shamir's work on the role of riddles in religion (Patt-Shamir 2003).

12 Thus, in portraying the riddle, Maimonides portrays a complicated picture of a complicated form of life, which contains both the concept of 'absolute transcendence' which renders problematic the metaphysical consolations that are sought within one's life with God, along with the principles of right conduct that insist on bringing the idea of absolute transcendence to bear on human life, in order to shape, reform and redeem it.
} 
In his Tractatus Logico Philosophicus, Wittgenstein referred to a variation of Maimonides' great riddle of transcendence with the following words: 'The "experience" which we need to understand logic is not that such and such is the case but that something is; but that is no experience ... (Wittgenstein 1988: T, 5.552). In his 'Lecture on Ethics', he referred to an experience/apprehension/ contemplation of 'something' transcendent and of absolute value as a 'paradox', focusing on the experience of 'wonder at the existence of the world'. As an experience, it is a contingent fact that takes place in time and space. As such, it is in the world, an immanent fact in it. Yet, it is presumed to be of 'something' transcendent, i.e., 'outside' the world, 'outside' space and time, and as such, of absolute value. It is, thus, a 'paradox':

But when I say they are experiences, surely, they are facts; they have taken place then and there, lasted a certain definite time and consequently are describable. And so ... I must admit it is nonsense to say that they have absolute value. And I will make my point still more acute by saying 'It is the paradox that an experience, a fact should seem to have supernatural value. (Wittgenstein 1993: 43) 13 $^{13}$

Wittgenstein insisted that the verbal expression which we give to such an experience is nonsense (Wittgenstein 1993: 41).

Similarly to Wittgenstein, in Maimonides too, the climactic moment of apprehension of the divine name that defeats suffering, in which the great riddle of transcendence reaches its climax, is described as a paradox: it is a moment during which the dichotomies between transcendence and immanence, time and eternity, contingency and necessity collapse.

In attempting to gesture at this great riddle, (not at its solution) Maimonides runs against the boundaries of language, against the walls of the cage, as Wittgenstein puts it (Wittgenstein 1993). Like Wittgenstein, he, too, embraces silence:

Glory, then to Him who is such that when the intellects contemplate His essence, their apprehension turns into incapacity; and when they contemplate the proceeding of His actions from His will, their knowledge turns into ignorance; and when the tongues aspire to magnify Him by

${ }^{13}$ Kierkegaard too, emphasized the role of paradox and the absurd within the life of faith in his analysis of the figure of Christ and what it takes to follow him in his Practice in Christianity (Kierkegaard 1991). For the role of the absurd in Kierkegaard's Fear and Trembling and how it relates to the riddle of the binding of Isaac, see Patt-Shamir 2003. 
means of attributive qualifications, all eloquence turns into weariness and incapacity. (I/58, p. 137) ${ }^{14}$

\section{BIBLIOGRAPHY}

Benor, Ehud Z. 1995. 'Meaning and Reference in Maimonides' Negative Theology', Harvard Theological Review, 88/3: 339-360

Blumenthal, David R. 2006. Philosophic Mysticism: Studies in Rational Religion (Ramat Gan: Bar Ilan University Press)

Cornevale, Franco A. 2009. 'A Conceptual and Moral Analysis of Suffering', Nursing Ethics, 16/2: 173-183

Davies, Daniel. 2011. Method and Metaphysics in Maimonides' Guide of the Perplexed (Oxford: Oxford University Press)

Diamond, Cora. 1995. 'Riddles and Anselm's Riddle', in The Realistic Spirit: Wittgenstein, Philosophy, and the Mind (Cambridge, Massachusetts: MIT Press), pp. 267-290

Edwards, S. D. 2003. 'Three Concepts of Suffering', Medical Health Care Philosophy, 6: 59-66

Even-Chen, Alexander. 2008. 'God's Positive Attributes in Maimonides' Philosophy', Daat, 63: 19-45 [in Hebrew]

Gruenwald, Ithamar. 1991. 'Maimonides' Quest beyond Philosophy and Prophecy', Perspective on Maimonides: Philosophical and Historical Studies, ed. by Joel L. Kraemer (Oxford University Press), pp. 141-157

Kasher, Hannah. 1994. 'Self-Cognizing Intellect and Negative Attributes in Maimonides' Theology', Harvard Theological Review, 87: 461-472

Kierkegaard, Søren. 1983. Fear and Trembling, edited and translated by Howard V. Hong and Edna H. Hong (Princeton, New Jersey: Princeton University Press)

Kierkegaard, Søren. 1991. Practice in Christianity, edited and translated by Howard V. Hong and Edna H. Hong (Princeton, New Jersey: Princeton University Press)

Lorberbaum, Menachem. 2011. Dazzled by Beauty: Theology as Poetics in Hispanic Jewish Culture (Jerusalem: Ben Zvi Institute) [in Hebrew]

Maimonides, Moses. 1963. The Guide of the Perplexed, trans. by Shlomo Pines (Chicago: University of Chicago Press)

Margolin, Ron. 2011. Interior Religion: The Phenomenology of Inner Religious Life and its Manifestation in Jewish Sources from the Bible to Hasidic Texts (Gamat Gan and Jerusalem: Bar Ilan University Press and Shalom Hartman Institute) [in Hebrew]

\footnotetext{
${ }^{14}$ This research was supported by the Israel Science Foundation (grant No. 1110/13).
} 
Patt-Shamir, Galia. 2003. 'To Live a Riddle: The Case of the Binding of Isaac', Philosophy and Literature, 27/2: 269-283

Pines, Shlomo. 1979. 'The Limitations of Human Knowledge according to alFarabi, Ibn Bajja and Maimonides', in Studies in Medieval Jewish History and Literature, ed. by Isadore Twersky (Cambridge, Mass: Harvard University Press), pp. 82-109

Pines, Shlomo. 1986. 'The Philosophical Purport of Halachic Works and the Purport of the Guide of the Perplexed', in Maimonides and Philosophy, ed. by Shlomo Pines and Yirmiahu Yovel (Dordrecht: Martinus Nijhoff), pp. 1-14

Pines, Shlomo. 1963. 'Translator's Introduction: The Philosophical Sources of the Guide of the Perplexed', in Maimonides: The Guide of the Perplexed, trans by Shlomo Pines (Chicago: Chicago University Press), pp. vii-cxxxiv

Reines, Alvin J. 1986. 'Maimonides' True Belief Concerning God: A Systematization', in Maimonides and Philosophy, ed. by Shlomo Pines and Yirmiyahu Yovel (Dordrecht: Martinus Nijhoff Publishers), pp. 24-35

Seeskin, Kenneth. 2000. Searching for a Distant God: The Legacy of Maimonides (New York and Oxford: Oxford University Press)

Verbin, N. 2010. Divinely Abused (London and New York: Continuum)

Verbin, N. 2000. 'Religious Beliefs and Aspect Seeing', Religious Studies, 36: 1-23

Verbin, N. 2011. 'Wittgenstein and Maimonides on God and the Limits of Language', European Journal for Philosophy of Religion, 3/2: 323-345

Wittgenstein, Ludwig. 1988. Tractatus Logico Philosophicus, trans. by C. K. Ogden (London and New York: Routledge)

Wittgenstein, Ludwig. 1993. 'Lecture on Ethics', in Philosophical Occasions 19121951 (Indianapolis and Cambridge: Hackett Publishing Company), pp. 37-44 